\title{
前頭洞疾患に対する $\mathrm{T}$ チューブ留置法
}

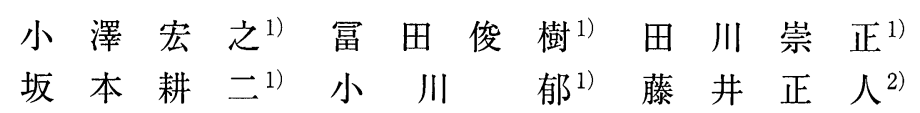

要旨: 前頭洞疾患の 3 症例に対して鼻外切開による襄胞開放術後に, 胆管ドレナージ用の Tチューブ を留置し良好な経過を得た。1 例目は 76 歳男性で前頭洞癌に対する前頭蓋底手術後に生じた前頭洞炎 に対して 2 回の前頭洞開放術・ドレナージを行うも再発した症例。2 例目は 41 歳男性で過去に 5 回の 前頭洞開放術を施行した後に再発した症例。 3 例目は 59 歳女性で 40 年前に鼻外切開による前頭洞開放 術を他院で施行したが再発した症例であった。Tチューブは脱落が少なく，固定を必要としないなどの 利点がある。 3 症例とも長期間 $\mathrm{T}$ チューブを留置しているが, 再発を繰り返す難治性前頭洞炎・襄胞症 例では長期間安定した状態を維持できる Tチューブ留置法が有効である。

キーワード：難治性前頭洞炎・襄胞, Tチューブ留置, 鼻外アプローチ

Summary Treatment of frontal sinusitis and cyst using a T-shaped bile duct tube:

Hiroyuki Ozawa $^{1)}$, Toshiki Tomita ${ }^{1)}$, Takamasa Tagawa ${ }^{1)}$, Kouji Sakamoto ${ }^{1)}$, Kaoru Ogawa ${ }^{1)}$ and Masato Fujii ${ }^{2)}$. ${ }^{1)}$ Department of Otolaryngology, School of Medicine, Keio University, Tokyo, ${ }^{2)}$ Department of Otolaryngology, National Hospital Organization Tokyo Medical Center, Tokyo

We placed T-shaped bile duct tubes (T-tubes) in the naso-frontal ducts of three patients with recurrent frontal cysts or sinusitis resulting from drainage by the extranasal approach. The first patient developed recurrent frontal sinusitis after anterior skull base resection for ethmoidal squamous cell carcinoma. The second patient had undergone 5 operations for a recurrent frontal cyst. The third patient experienced relapse of a frontal sinus cyst 40 years after initial surgery. A T-tube was placed for over a year in all three cases. The T-tube was effective in draining sinus discharge and demonstrated long-term stability without the need of fixation. We recommend the use of T-tubes for cases of frontal sinusitis, those with cysts in which there is difficulty controlling infection, or cases in which it is difficult to maintain the opening of the naso-frontal duct.

Key words: frontal sinus cyst, frontal sinusitis, T-shaped bile duct tube, extranasal approach

[Received May 12, 2006, Accepted Aug. 1, 2006]

\section{はじめに}

前頭洞譲胞や前頭洞炎に対する外科的治療は,

1) 慶應義塾大学医学部耳鼻咽喉科

2) 国立病院機構東京医療センター耳鼻咽喉科

[平成 18 年 5 月 12 日受付, 平成 18 年 8 月 1 日受理]
病的粘膜をすべて除去し前頭洞を充填する手術

と, 洞内粘膜を保存し鼻前頭管を開放する手術の 二通りに大別される。副鼻胿粘膜は換気を改善す ることで正常化が期待できることから, 我々の施 設では後者の術式を選択することが多い。また, 副鼻腔手術は内視鏡を用いた手術が主体となって 


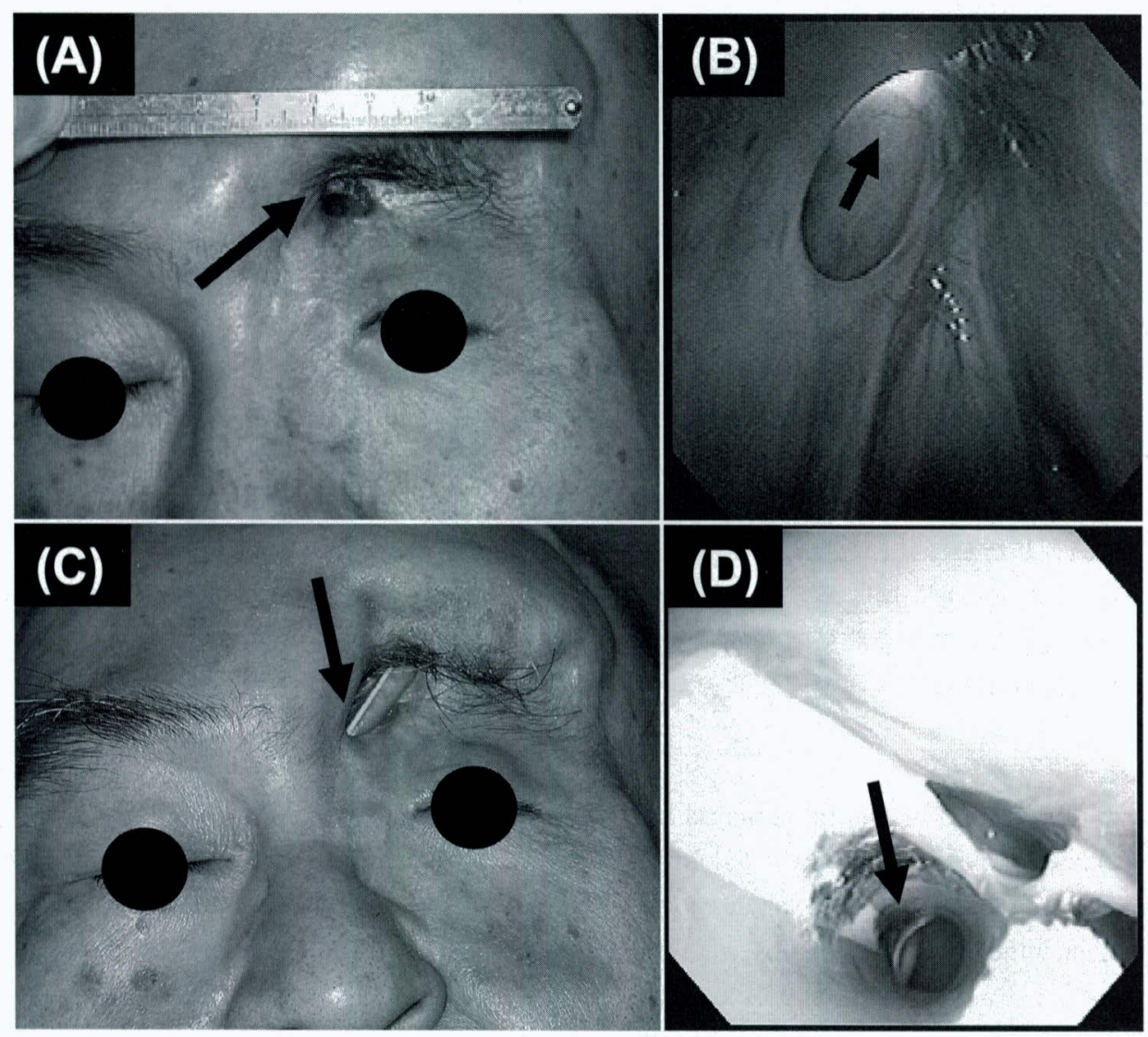

図 1 症例 1 の術前後の所見

(A) 術前の前額部所見。矢印の部位に炎症性肉芽を認めた。

(B) 術前鼻内所見。矢印の部位で鼻前頭管は膜性に閉塞していた。

(C) 術後の前額部所見。Tチューブが留置され炎症所見が改善していた。

(D) 術後の鼻内所見。チューブより前頭洞を観察すると洞内の炎症が改善した。

おり，近年は手術器具の改良・開発に伴い，前頭 洞疾患に対しても積極的に内視鏡治療が行われ良 好な治療成績を収めている11。しかし依然として 開放した鼻前頭管の閉塞を繰り返し治療に難渋す る症例を経験する。このような難治例に対しては 外切開による前頭洞開放が適応となり，またその 際には炎症のコントロールのために何らかのドレ ナージチューブを留置する必要がある。チューブ 留置の方法やチューブの選択は施設および術者ご とに異なり，我々の施設でも過去にペンローズド レーン, シリコン単チューブ, J-VACドレーン などの様々なチューブが用いられていた。これら のドレーンはチューブの固定方法に問題があるた め自然脱落を生じることもまれではない。

我々は背景の異なる前頭洞疾患 3 例において,
キリアン法に準じた外切開アプローチで洞内を開 放後に，胆管ドレナージに用いる T千ューブを 加工し前頭洞および鼻前頭管に留置することで良 好な経過を得た。これらの症例を呈示し若干の文 献的考察を記す。

\section{症例提示}

症例 $1: 76$ 歳男性

前篩骨洞癌に対して 2001 年 9 月前頭蓋底手術 を施行した。手術の際に左前頭洞は腫瘍ともに切 除し, 腫瘍に近接する硬膜も切除した。欠損硬膜 は帽状腱膜で再建した。前頭洞は側頭筋を充填 し, 頭蓋底と眼窩の内側壁はチタンメッシュで再 建した。術後は経過良好であったが, 前頭洞開口 部が閉塞し前頭洞炎を生じたため, 2002 年 12 月 

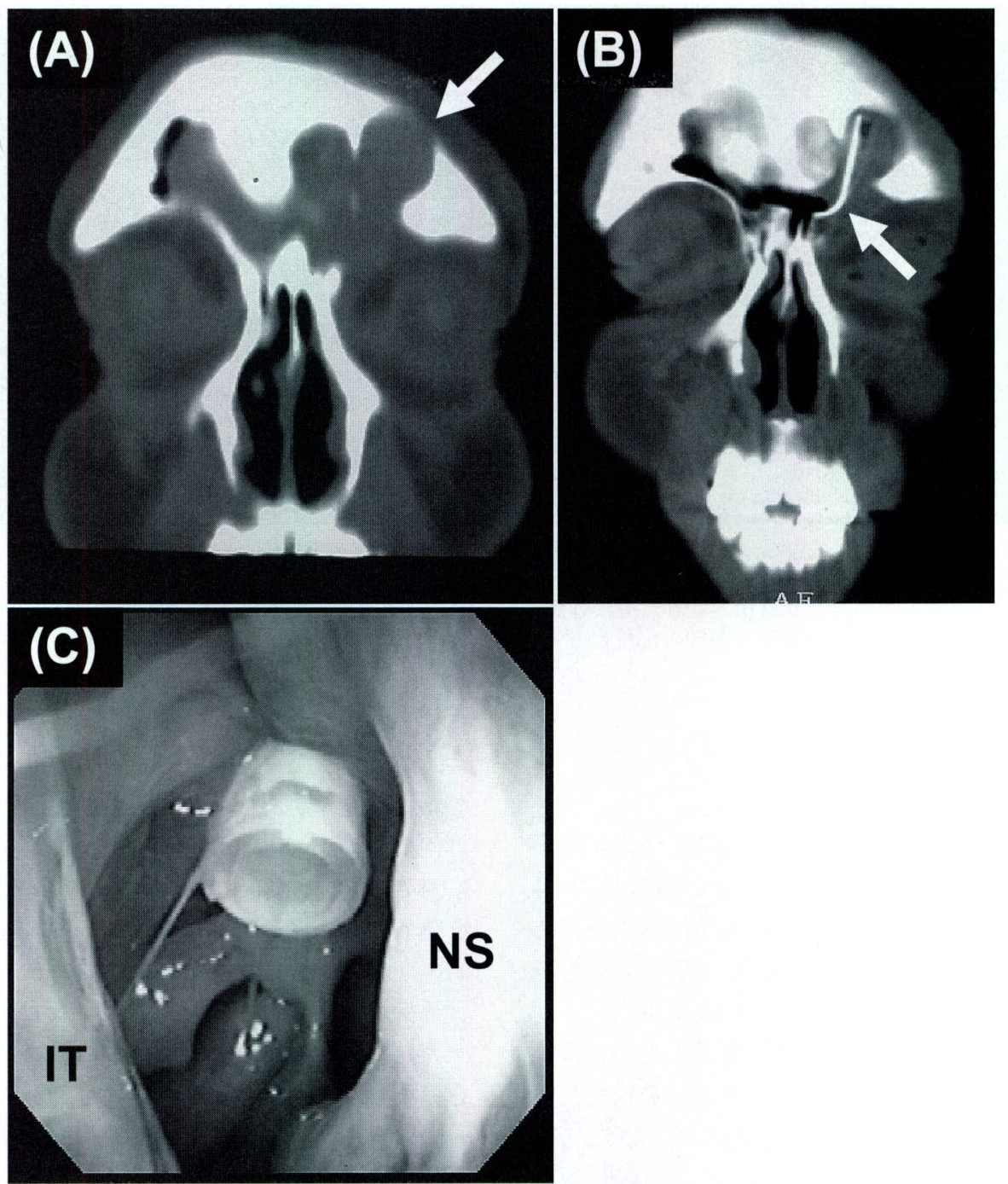

図 2 症例 2 の術前後の所見

(A) 術前の CT 冠状断。矢印の部位に囊胞病変を認めた。

（B）術後の CT 冠状断。矢印の部位に Tチューブを留置した。前頭洞に含気はあるもの の軟部組織陰影を認め, 炎症の遷延が疑われた。

(C) 術後の右鼻内所見。鼻中隔が切除され $\mathrm{T}$ チューブが留置された。

NS：鼻中隔 IT；下鼻甲介

に再建に用いたメッシュプレートを除去しペン ローズドレーンを留置した。2003 年 7 月にチュー ブが自然脱落した。前頭洞開口部が再閉塞したた めに前頭洞炎をきたし, 前頭洞の感染が皮下に及 んできたため同年 10 月に手術を行い, ペンロー ズドレーンを再び留置した。術後, 徐々に膿性鼻 汁が増加したためドレーン感染と判断し 2004 年 4 月にドレーンを抜去した。2004 年 9 月に左眼瞼
上が腫大し，その後に前額部の皮膚が自潰した (図 1A)。鼻内より観察すると鼻前頭管は膜性に 閉鎖していた（図 1B）。保存的治療で改善しない ため, 2005 年 2 月に局麻下に KTP レーザーを用 いた鼻前頭管開大を行い， T チューブ留置術を施

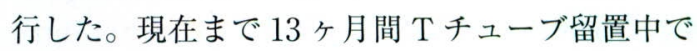
あるが, 経過は良好で炎症の再燃および癌の再発 を認めていない（図 1C,D)。 


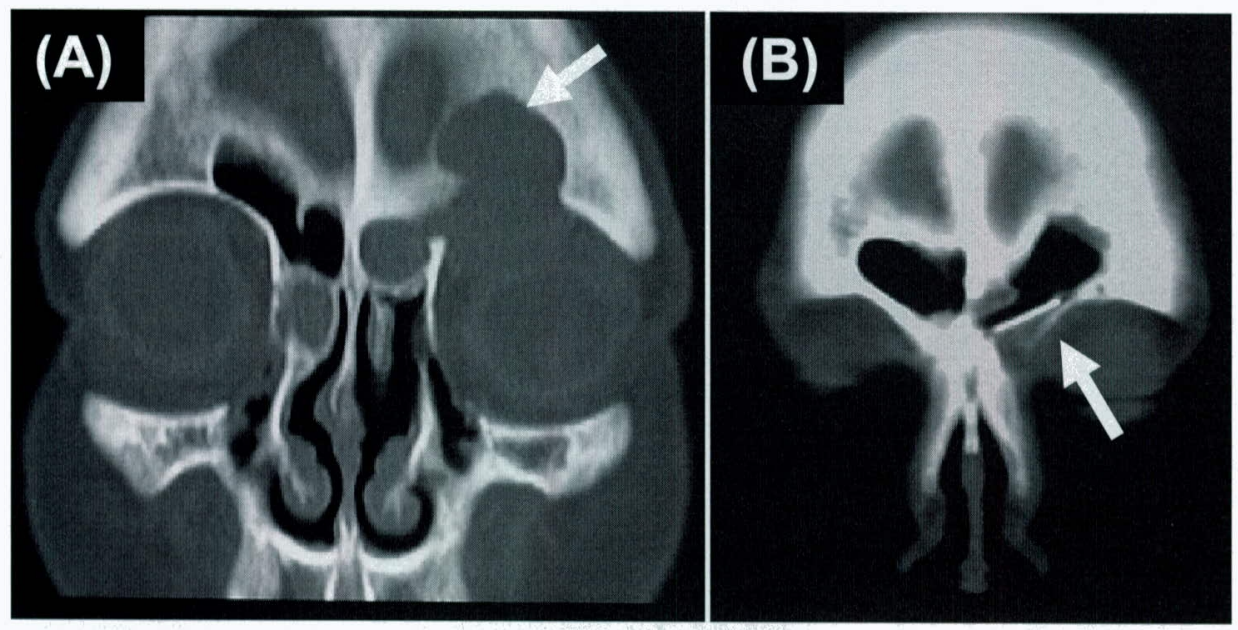

図 3 症例 3 の術前後の所見

(A) 術前の CT 冠状断。矢印の部位に衰胞病変を認め, 眼㸗内への進展を認める。鼻前頭管は 骨性に閉塞し輁胞様となり，更に外側に前頭洞囊胞が連続していた。

(B) 術後の CT 冠状断。矢印の部位に T チューブ水平部が留置されている。前頭洞の含気は 著明に改善した。

症例 $2: 41$ 歳男性

1977 年, 1979 年, 1989 年に他院にて前頭洞手 術を受けた。前額部の腫大を主訴に 1999 年 12 月 に当院を初診した。CTにて左前頭洞囊胞を認め (図 2A)，2000 年 2 月に鼻外前頭洞開放術を行い J-VAC ドレーンを留置した。2000 年 4 月に, 固 定していた糸が外れチューブが脱落した。以降は 外来で前頭洞ブジーを行っていたが, 鼻前頭管が 再閉塞しさらに前額部痛が出現した。2003 年 6 月に再手術を行い，J-VACドレーンを留置した。 外来経過観察中にチューブの閉塞をきたし, 再び 左前頭部腫大および前頭部痛が出現したため, 2005 年 2 月に T チューブを留置した。現在も T チューブ留置中で, チューブより膿性鼻汁の排出 があるため外来で洗浄を行っている（図 $2 \mathrm{~B}$, $2 \mathrm{C})$ 。

\section{症例 $3: 58$ 歳女性}

40 年前に鼻外切開による前頭洞開放術を他院 で受けた。左前頭部腫大が出現したため 2005 年 6 月に当科を受診した。CTにて前頭洞から眼窩 内に進展する囊胞性病変を認め, 一部頭蓋底に骨 欠損を認めた。また鼻前頭管は囊胞化し骨性に閉 鎖していた（図 3A）。画像検查上, 鼻前頭管部 に囊胞構造がありさらに外側に別の囊胞が連続し
ている可能性があること, および前回手術時に鼻 外切開を行っていることを考慮し， 2005 年 7 月 に鼻外切開による前頭洞開放 T チューブ留置術 を施行した。術後 6 ケ月の CT (図 3B) で前頭 洞の含気は改善し経過は良好である。

手術所見：症例 3

キリアン法に準じて眉弓部を切開し前頭洞囊胞 を開放した。囊胞は単胞性であったが, 鼻前頭管 への移行部は狭小化していたため開大した。前頭 洞中隔および鼻中隔の上方を一部除去したのち, 骨性に閉塞した鼻前頭管をドリルで開大した（図 $4 \mathrm{~A})$ 。胆管ドレナージ用 T千ューブ（18Fr）を

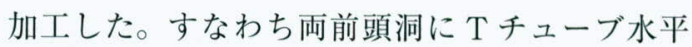
部が跨るように適当な長さに切断し, 水平部の上 部構造を除去し水平部はどの部位からでもドレ ナージができるようにした23)。Tチューブ垂直 部は可能な限り短く, かつ中鼻道に先端が到達す

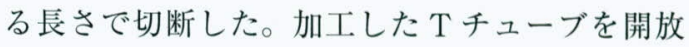
した前頭洞に留置した（図 4B，4C）。その際に チューブの切断面が粘膜に当たらないように注意 した。また術中に鼻内よりチューブが容易に抜去 できることを確認した。眉弓部を縫合し鼻腔内に ガーゼを留置し手術を終了した。 

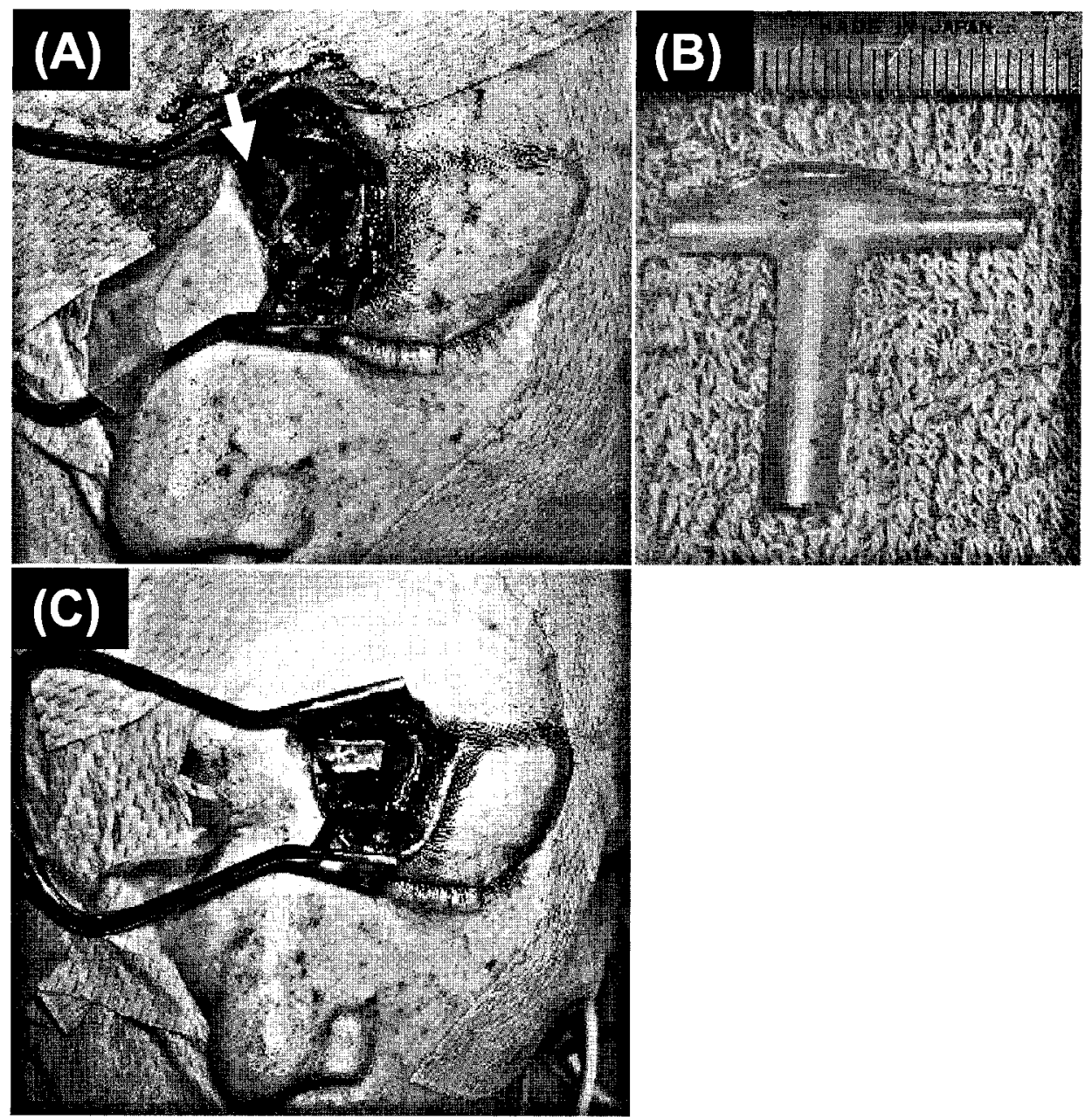

図 4 術中所見

(A) 霟胞開放後。前頭洞中隔を切除 (矢印)。

（B） Tチューブを加工。水平部の上部構造を切除。垂直部は中鼻道に開口寸るように短く切 断。

（C） Tチューブ留直後。水平部が而側の前頭洞に跨るように留置した。

\section{考察}

経過の異なる 3 症例に胆管ドレナージに用いる Tチューブを加工して留置し，良好な経過を得 た。3症例とも鼻外切開手術の既往があり，鼻外 切開を行うのに患者サイド，医療サイドとも抵抗

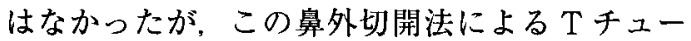
ブ留置法は，既に鼻外切開を行っている症例だけ でなく内視鏡手術だけでは対応しきれない前頭洞 炎症性疾患に有用である。症例 1 では頭蓋底手術 の既往があり，前頭洞は洞内粘膜を除去し頭蓋底
と連続することで前頭洞の頭蓋内化を計っていた が，術後に頭蓋内容の拡張に限界があったため， 結果として死腔が残存し，かつ鼻前頭管が狭小化 したため感染を生じたと考えている。同部位は頭 蓋底手術の影響で瘏悢化し骨削開して鼻前頭管を

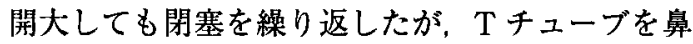
前頭管のステントとして留置することで炎症のコ ントロールが可能となった。症例 2 では過去 5 回 の手術で前頭洞中隔および前頭洞底の骨構造を除 去したが前頭洞の炎症は遷延した。また留置して いたJ-VAC ドレーンがドレナージルートとして 
不穴定であった。Tチューブ留置後はチューブよ りの滲出は継続しているものの, ドレナージが安 定したことで疼痛や前額部の腫脹などの症状はな く，患者本人も満足のいく結果となった。症例 3 では鵕前頭管は骨性に閉塞した罣胞構造をもち, 更に外側に㶅胞様の前頭洞が連続していたことか ら，内視鏡下手術では外側の前頭洞との交通をつ けるのが困難と判断した。鼻外切開により前頭洞

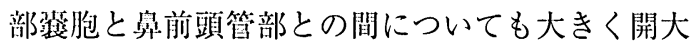
することができ，Tチューブ留置により良好にド レナージされた。

難治性の前頭洞炎症性疾患に対して洞内粘膜を 保存する手術を行う際に鼻前頭管の開大が最も重 要である。元来，奥前頭管は解剖学的に狭小であ り開大するには限界がある。また手術操作に伴う 洀痕形成が加わることでさらに狭小となり反復手 術例では条件が惩くなる。Draf らは前頭洞疾患 の内視鏡下手術を以下の 3 つに分類している4。 多前頭管より下部の構造を取り除く最低限の手術

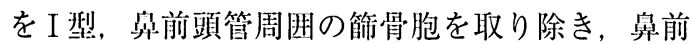
頭管を開大する手術を II 型，両側の前頭洞底部 と前頭洞中隔および鼻中隔の上方構造を取り除く 手術を III 型としている。前頭洞炎や前頭洞外傷 や良性腄瘍に対して病巣の進展範囲によりこれら の手術を選択することで 79 〜 $97.8 \%$ の症例で疾 㭧のコントロールが可能ではあるが，Draf III 型 手術を行っても再発を来す症例が存在する1)。

このような症例で感染や炎症のコントロールを 行うためには，手術で開大した鼻前頭管にドレ ナージチューブを留置する必要がある。チューブ は内胿が広く, 組織反応が軽微で, 自然脱落や感 染などのドレーントラブルが生じ難いものが求め られる。当科では過去にペンローズドレーン・ J-VAC ドレーン・シリコン単チューブなどが用 いられていたが，内胿の狭窄や自然脱落を生じる ことがあり，またその結果として症例 $1 ， 2$ のよ うに頻回の手術を要する症例もあった。Tチュー ブ留㯰については 1986 年渡部らがその有效性に ついて報告している5)。Tチューブは比較的弾性 で赑前頭管の保持に適しており，内胿が広く疎通 性が良好で洗浄が容易に行えるという特徴があ る。またシリコン製で組織反応が少なく，留置に 伴う違和感も生じにくい。またチューブの加工が
容易である。

鼻外切開による Tチューブ留置術を行う際の 留意点として以下の 4 点が挙げられる。(1)確実な 前頭洞開放：広い視野で安全に前頭洞中隔や奥中 隔の上方構造, 前頭洞底部を除去することが可能 であり，Draf の III 型に準じた前頭洞底部の除去 を行うことで前頭洞疾患のコントロールをより確 実に行うことができる。(2)チューブ形状を利用し た固定：前頭洞中隔を除去し Tチューブを生理 的な方向に留置することで，ナイロン糸などによ る固定は不要となり， Tチューブの形状から自然 脱落を生じにくくなる。(3)水平部の加工：病巣の 進展範囲に合わせて，チューブの水平部の距離を 調整することで確実にドレナージルートを確保で きる。特に外側に位置する前頭洞堙胞に対しては 有用である。(4)垂直部の調節：Tチューブの垂直 部は可能な限り短くかつ鼻粘膜に尖端が接触しな いように加工する。チューブ垂直部が長いと痂皮 によるチューブ内腔の閉塞が生じやすくなる。ま たチューブ先端が鼻粘膜に接触すると肉芽が形成 されやすい。さらにチューブは番内より容易に抜 去できることを術中に確認する。これにより外来 で局所麻酔下に問題なく抜去可能となる ${ }^{3.5 .6)}$ 。

チューブの留置期間については, 開放部位の上 皮化が完成するのに約 3 週間かかるとされている ため ${ }^{7)}$, 最低でもこの期間は留置を継続する必要 がある。過去の報告では 3 ヶ月〜 6 ヶ月としてい るが3.5.6), 難治症例では再発も少なくない。野田 らは, 難治例では可及的長期のチューブ留置が望 ましく, 症例によっては永久留置をしてもよいと 報告している2)。我々も頻回の手術を行ってきた 症例では患者本人の負担を考えて, 永久的に $\mathrm{T}$ チューブを留置することを検討してよいと考えて いる。

\section{結 語}

難治性前頭洞疾患に対する鼻外切開による前頭 洞開放術・Tチューブ留置術について報告した。 Tチューブは内腔が広くドレナージチューブとし て優れており，組織反応が少なく長期間の留置が 可能である。またチューブの加工が容易であり チューブの形状を生かすことにより，特別な固定 が不必要で安定性に優れている。今回報告した症 
例では過去に鼻外切開の既往があり鼻外手術に際 しての支障はなかった。再発を繰り返す難治性前 頭洞疾患では, 鼻外切開を行い確実に鼻前頭管を 開大し Tチューブを留置する本法が有用と考え る。Tチューブの留置期間については, 炎症の改 善の具合により個々の症例で判断すべきである が，難治症例については永久留置を行っても良い と考えている。

\section{文献}

1) Weber R, Draf W, Kratzsch B, et al: Modern concepts of frontal sinus surgery. Laryngoscope $111: 137-146,2001$.

2）野田一郎，斉藤 等，藤枝重治，他：前頭・簛骨 洞囊胞に対する Tチューブ長期留置法の検討。耳
鼻臨床，補 63：1114-117, 1993.

3) Yamasoba T, Kikuchi S, Higo R: Transient positioning of a silicone $\mathrm{T}$ tube in frontal sinus surgery. Otolaryngol Head Neck Surg $111: 776-780$, 1994.

4) Draf W: Endonasal micro-endoscopic frontal sinus surgery: the Fluda concept. Operative Technique Otolaryngol Head Neck Surg $2: 234-240,1991$.

5）渡部 俊, 和田 繁, 松尾浩一, 他：前頭洞襄胞 に対する Tチューブの使用経験。耳鼻臨床，79： 1811-1814, 1986.

6）山本英一, 兵 行孝, 川崎康一郎：前頭洞手術に おける胆管用ドレナージチューブの使用経験（追 試)。耳喉頭頸, 67：984-986, 1995.

7）古和田勲，小野寺亮，小林信一，他：前頭・篩骨 睪胞の臨床的, 病理組織学的検討。耳鼻, 25 ： 219-229, 1979 